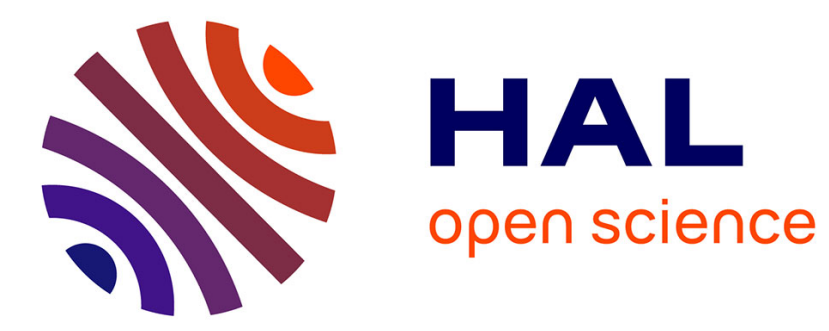

\title{
Is There a French Postclassical Narratology?
}

John Pier

\section{To cite this version:}

John Pier. Is There a French Postclassical Narratology?. Greta Olson (dir.); Introduction de M. Fludernik et G. Olson. Current Trends in Narratology, Walter de Gruyter, pp.97-124, 2011, Narratologia. hal-01229438

\section{HAL Id: hal-01229438 \\ https://hal.science/hal-01229438}

Submitted on 30 Nov 2015

HAL is a multi-disciplinary open access archive for the deposit and dissemination of scientific research documents, whether they are published or not. The documents may come from teaching and research institutions in France or abroad, or from public or private research centers.
L'archive ouverte pluridisciplinaire HAL, est destinée au dépôt et à la diffusion de documents scientifiques de niveau recherche, publiés ou non, émanant des établissements d'enseignement et de recherche français ou étrangers, des laboratoires publics ou privés. 


\title{
JOHN PIER
}

(Tours and Paris)

\section{Is There a French Postclassical Narratology?}

\begin{abstract}
This brief historiographic study shows that French narratology does not divide into a "classical" narratology and "postclassical narratologies" in the way spoken of by David Herman or into the hyphenated "narratologies" identified by Ansgar Nünning. The principal players (Barthes, Todorov, Genette) turned to other pursuits, and Ricœur's watershed Time and Narrative opposed "semiotic rationality" to "narrative intelligence" of a hermeneutic type while the disappearance of structuralist linguistics as a "pilot science" was not succeeded in France by the "renaissance" of narratology that occurred in other countries starting in the early 1990s. Theoretically oriented research on narrative continued, but not always under the label of narratology, some of it in non-literary fields. French discourse analysis appears to offer a conceptual and methodological framework for addressing the concerns of postclassical narratology.
\end{abstract}

\section{Introduction}

Narratology came into existence under the banner of a science of literature. To justify its status as a principled set of postulates and analytic and descriptive procedures, it, along with other disciplines adhering to the structuralist model, adopted structural linguistics as a "pilot-science." Such credentials, it was thought, provided narrative theory with a reliable paradigm for working out a theoretical model common to all narratives, both existent and possible. Inspired by Saussure, the focus on a narrative langue underlying all narratives as opposed to the narrative parole of individual narratives was widely embraced, as was the attendant emphasis on description over interpretation. However, when one looks more closely at the systems actually adopted by narrative theorists, the intended role of structural linguistics - to act as a unifying paradigm-appears far less reassuring. Hence, Claude Lévi-Strauss's (1967 [1955]) (pre)narratological analysis of myths remodels Propp's "functions" into "mythemes" following the example of the refinement of the Saussurean phoneme by Trubetskoj and Jakobson; A. J. Greimas's (1983 [1966]) semantic theory, including its semiotic square and model of actantial roles, owes much to 
Hjelmslev's rereading of Saussure and to Tesnière's syntactic analysis of the noun phrase; in positing "a homological relation between sentence and discourse" (Barthes 1977 [1966]: 83), Roland Barthes's "translinguistics" beckons toward a theory and practice of discourse analysis that did not yet exist (cf. Herman 2001, 2005b: 574); Tzvetan Todorov's (1969) three-level model of narrative grammar (semantic, syntactic, verbal) is inspired by the Medieval Modists' universal grammar and proposes to equate character with the noun and action with the verb; finally, Gérard Genette's recourse to "a kind of linguistic metaphor" making it possible "to organize, or at any rate to formulate, the problems of analyzing narrative discourse according to categories borrowed from the grammar of the verb" (Genette 1980 [1972]: 30) evokes traditional sentence grammar more than it does linguistic theory. The early narratologists saw individual narratives as bearing a "narrative message" rendered through the identifiable constituents and combinatory principles of a common semiotic system which was susceptible to linguistically inspired description (story vs. discourse and its various derivatives). Yet the diverse postulates, methodologies, and goals adopted for proceeding with this analysis increasingly cast doubt on any appeal to structural linguistics as a pilot-science for a theory of narrative. From the perspective of one French linguist as recently as 2000: "Narratology, despite a number of rather metaphorical terminological borrowings ('narrative proposition,' 'mode,' etc.) has experienced a development that owes little to linguistics" (Mainguenau 2000: 10). ${ }^{1}$

\section{From Classical to Postclassical Narratology}

From the perspective of "postclassical" narratology, these divergences may be surprising. Proposed by David Herman in 1997 and explicated more fully in 1999, this term designates the re-emergence and transformation of narratology starting in the late 1980s, several years after the decline of "classical" narratology. ${ }^{2}$ As Herman makes clear, if postclassical narratology is more inclusive and open-ended than its predecessor, both are committed to perfecting models for the description and explanation of narrative seen as a complex structure of levels that lends itself to analysis in ways that the linguistic turn has durably conferred on narrative theory (cf. Herman 1999). And indeed, it has been suggested by Monika Fludernik that:

$1 \quad$ All translations from French sources are my own.

2 Herman (1999: 4), referring to a statement by Mieke Bal, places "the high-water mark of classical theorizing about narrative" in 1979 at the time of the conference "Synopsis 2: Narrative Theory and Poetics of Fiction" held at Tel Aviv University. 
One way to map the history of narratology is [...] to see it as adopting linguistic paradigms one by one as they arose in the twentieth century-structuralism (classical narratology); generative linguistics (text grammars); semantics and pragmatics (speech act theory, politeness issues, etc.); text linguistics (conversation analysis and critical discourse analysis); and now cognitive linguistics (cognitivist narratology). (Fludernik 2005: 48)

She further points out that the failure of classical narratology to provide adequate evidence to back up the empirical relevance of its linguistic categories has now been largely compensated for by the move of linguistics into cognitive concerns (to which discourse analysis and pragmatic linguistics might also be added), thus providing narratologists with invigorated linguistic models (Fludernik 2005: 50). In retrospect, then, divergences between the various models of classical narratology such as those pointed out above can be regarded as a harbinger not only of the crisis that was to seize the initial theories and models, but also of the dynamics of discovery characteristic of narratological research over the past twenty years. This being the case, it is important to bear in mind that poststructuralist narratology is not to be conflated with postclassical narratology, of which it is but one variety.

Before inquiring into whether and in what sense a properly French postclassical narratology exists, it must be noted that the notion itself has been generated in a context marked largely by English-language scholarship; few Francophone narrative theorists think of their work in these terms. The expansion and multiplication of paradigms characteristic of postclassical narratology result from developments that are not wholly indigenous to French researchers or that are approached from a different angle. Thus, to avoid facile and potentially misleading assimilations, a few words on the key features of postclassical narratology are in order.

The single most decisive factor in the rise of the new paradigms for the study of narrative is the integration of context into narrative theory and analysis. This is reflected not only in the evolution of linguistic theories mentioned above, but also by four major domains of investigation. The contextualization of narratology has produced - to mention only one example-feminist narratology, one of whose endeavors has been to question the formal neutrality of narrative categories by pointing to the genderization of voice, plot structure, etc. A text may provide cues to such genderization which in turn elicit in the reader an interpretive strategy and moves that were bracketed out by the early narratologists. As a result of these factors being taken into account, the context of reception (ideological, social, psychological, ethical, etc.) is integrated into the description and analysis of texts, as is the impact of reading on the processing of stories (also examined by psycho-narratology). A second domain is associated with the so-called "narrative turn" that gathered speed during the 1990s 
(but that was already evident in the celebrated issue of Communications published in 1966): this consists of an expansion of the corpus beyond literary fiction to include a wide variety of narratives such as conversational storytelling, narrative in law, medicine, psychoanalysis, etc. In turn, the increased variety of narratives studied by postclassical narratology has opened up yet another dimension of investigation: the narrative elements contained in poetry and drama (transgeneric narratology) and non-verbal forms of narrating in the plastic arts and music as well as, more recently, in the digital media (intermedial narratology). Finally, the expansion of classical narratology to include narratives beyond the literary corpus has gone hand-in-hand with a new interdisciplinarity brought to bear on the object of study and has resulted in a cross-fertilization of insights into narrative gained from disciplines and methodologies that formerly developed in isolation from one another: Fludernik's (1996) "natural" narratology, for example, integrates research in the field of conversational storytelling; and cognitive narratology, as practiced by David Herman or Manfred Jahn, draws heavily on research conducted in the cognitive sciences. These various developments have ushered in a more synthetic and integrative approach to narrative than the earlier text-centered approach (cf. Herman 1999: 11): narrative categories are no longer seen "as 'features' or 'properties' of narrative texts, but as implied reading potentials informing the interaction between reader and text, between interpretive communities and texts, between a culture's encoded ideology and a reader's compliant or resistant decoding" (Rimmon-Kenan 2002 [1983]: 145). In sum, "narratology," says Herman, once "a subfield of structuralist literary theory, $[\ldots]$ can now be used to refer to any principled approach to the study of narratively organized discourse, literary, historiographical, conversational, filmic, or other" (1999: 27, n. 1).

Postclassical narratology is not a unified undertaking, but rather groups together a variety of more or less overlapping paradigms and models and sometimes even incompatible theoretical premises, methodologies, and goals. For this reason it is just as frequently referred to as "narratologies." In an article that forms an essential sequel to Herman's landmark introductory text, Ansgar Nünning provides a survey which maps out the bewildering maze of "hyphenated and compound narratologies" that have sprung up over the years (cf. Nünning 2003: 258). ${ }^{3}$ He includes a useful (though admittedly oversimplified) list contrasting the characteristics of the "text-centered" structural narratology with those of the "contextoriented" newer narratologies. Nünning also points out the tension between the "science of narrative" (Todorov) and "self-styled narratologies,"

3 This article has also appeared in French in Pier/Berthelot (2010). 
noting that the latter are in some cases representative of other forms of literary theory and in others interpretive practices lacking in a theoretical foundation which is the hallmark of narratology — a state of affairs he attributes to what Jackson G. Barry (1990) has described as "Narratology's Centrifugal Force" (Nünning 2003: 240-48). Nevertheless, he has undertaken the daunting task of proposing an informal and tentative classification of no fewer than twenty-five narratologies into eight broad and somewhat heterogeneous categories in addition to some twenty applications, approaches, and contributions of varying narratological relevance (Nünning 2003: 249-51). Nünning further suggests that these theories can be located along a scale ranging from an "undertheorized" pole (New Historical Narratologies) to an "overtheorized" pole (Narratological Semantics based on possible worlds theory), with Feminist Narratology occupying a medium point (Nünning 2003: 256). Without enquiring into how either of these two configurations might be foreshadowed by classical narratology, he also observes, significantly, that structuralist narrative theory was not as "monolithic" as is often thought, as it breaks down into at least four "branches" or "variants": 1) Semantic Narratology/Narrative Semantics; 2) Story (oriented) Narratology (Syntactic Narrative Theory); 3) Discourse (oriented) Narratology; 4) Rhetorical/Pragmatic Narratology (cf. Nünning 2003: 246).

Nünning welcomes the broadening scope of narratological research. Yet for fear of undermining the very concepts and goals that are the defining features of narratology, he also cautions against the wholesale inclusion of ever-proliferating narrative theories under the blanket term "postclassical narratology." To maintain its status as a discipline and avoid the pitfalls of overextending and diluting its concepts and terminology, he therefore finds it desirable to draw a number of distinctions (cf. Nünning 2003: 257-62). First, narratology should not be considered synonymous with "narrative studies," a broad generic term covering various disciplines, approaches, and forms of criticism extending from theoretical issues, on the one hand, to practical criticism, on the other. Instead, it represents a particular form of narrative theory. Next, despite the interdisciplinary nature of their undertaking, the various narrative theories that have come into existence since the 1980s would best be subsumed under "narrative theory" as the study of the forms and functions of narrative. Thus historiographical, psychological, and linguistic narrative theories, for instance, each develop a set of methodological tools and research goals for examining the forms and functions of narrative that remain distinct from those of narratology. Moreover, narratology, whether classical or postclassical, is not to be confused with what Gerald Prince (1995) has termed "narratological criticism": a distinction between the two must be maintained even 
though the theory adopted by the critic will influence his interpretations and even though the narratologist's findings must ultimately undergo the examination of individual texts. Finally, Nünning questions whether all postclassical approaches can be said to constitute true extensions of narratological principles and methodologies. For instance, he contends that postcolonial narratology or deconstructive narratology are either mere applications of the narratological toolkit or theories of interpretation that have little in common with the theory of narrative.

The expansion of narratological concerns in fact harkens back to one of the founding texts, Barthes's "Introduction." This essay begins by affirming that narratives are countless, universal, transhistorical, and transcultural, that they can be conveyed by various media, that they are open to examination from different perspectives (historical, psychological, sociological, ethnological, esthetic, etc.), and that thanks to their universality they are open to description by reference to a "common model" for which Saussure's langue serves as a model (cf. Barthes 1977 [1966]: 79). The new narratologies, born out of methodologies and perspectives inspired from developments in discourse analysis, pragmatics and speech act theory, possible worlds logic, the cognitive sciences, etc., make no claim for a centralizing model such as that proposed by Barthes. Instead, as Nünning's argument shows, the new developments call for a rearticulation of the narratological program in response to the proliferation of theories and approaches as well as a redefinition of the place of narratology with regard to narrative studies, narrative theory, and criticism.

As welcome as these distinctions are, there still remains a certain tension between the positions outlined by Barthes and Nünning. If, as Barthes suggests, the domain of narrative analysis is all narratives, then in principle narrative theory - and in particular narratology whose defining characteristic, in line with the Russian Formalists' attempt to "uncouple theories of narration from theories of the novel" (Herman 2005a: 24), is the focus on narrative "as an autonomous object of study" (Ryan 2005: 344) independent of disciplines, media or genre-does indeed extend as far as narrative studies. This is so be it for no other purpose than to determine what is a narrative and what is not. ${ }^{4}$ Moreover, as the title of a book by Gerald Prince (1982) reminds us, the task of narratology is to specify the forms and functions of narrative. But are anthropological, philosophical or linguistic theories of narrative, allowing for the particularities of their respective disciplines and methodologies, not also concerned with the forms and functions of narrative? The fact that narratologically inspired

4 Herman (1999: 27, n. 1) implicitly acknowledges as much when he states that narratology is "more or less interchangeable with narrative studies" and then proceeds to narrow it down "to refer to any principled approach to the study of narratively organized discourse [...]." 
studies have since come to be viewed in a context-based framework (cf. Herman 1999: 8-9) 5 reflects a greater degree of interdisciplinary input from fields such as conversational storytelling analysis, for instance, which came into existence independently of narratology, and thus less emphasis on the elaboration of an overarching narrative model, but not on distinguishing narrative from other forms of cultural representation.

As to the delicate question of the relations between narratology and interpretation, the double-entry narratologies seem to have exposed a raw nerve. Where do systematic theoretical work end and the interpretation of individual works begin? And when does the interpretation of narratively organized discourse begin to reverberate within theory itself? Although there is no happy medium here and no generally valid rule for deciding where to draw the line, such questions, as shown by Tom Kindt and Hans-Harald Müller (2003), can be approached from four angles: 1) autonomist (structural narratology); 2) contextualist (postclassical narratology); 3) foundationalist (use of narratological concepts to monitor and evaluate interpretations); 4) heuristic (a narratology built up in such a way as to be neutral with regard to the type of interpretation of a text one might undertake but that remains grounded in poetics and rhetoric).

All in all, then, it would seem that the move from classical to postclassical narratology is less a revolution than an evolution (cf. Prince 2003b). Furthermore, the diversity of inspirations (linguistics, anthropology, rhetoric, psychoanalysis, philosophy) and divergences of approach and focus evidenced in the early formulations in fact served to lay the groundwork and point the way to subsequent developments that were to carry the debate forward, providing narratology with a new arsenal of paradigms and methodologies.

\section{Francophone Narrative Theory}

If Ansgar Nünning's attempt to chart out a road map for Englishlanguage postclassical narratology or narratologies was facilitated, in part, by the multiplicity of approaches to narrative study claiming (even abusively) the status of narratology, the same cannot be said of Francophone narratology. It would generally be recognized in France today that two narratologies exist, reflecting the distinction between histoire and discours:

one thematic in the broad sense (analysis of the story or narrative content), the other formal or, rather, modal (analysis of narrative as a mode of 'representation'

5 Note that contextual considerations were already foreshadowed by Prince in his observations on narrativity and point, even within his formalistic frame of reference (1982: chap. 5). 
of stories, in contrast to the nonnarrative modes like the dramatic and, no doubt, some others outside literature. (Genette 1988 [1983]: 16) ${ }^{6}$

In fact, there are few if any French practitioners of feminist, postcolonial or cultural studies operating under the banner of narratology. This is not to say, however, that narratological concepts are not, in some cases, included among the resources resorted to by specialists in these fields. Nor is it to say that Francophone narratology, even though still loosely associated with the structuralist movement by many, has not evolved since Genette's Nouveau discours du récit in 1983-a publication which, arguably, marks the cutoff date of classical narratology as practiced in France for close to two decades. Rather, it is a sign that French literary scholars did not by and large take part in the "renaissance" of narratology beginning in the late 1980s. The principal players had already adopted a different set of pursuits, and work carried on in narrative theory until early in the present decade and even beyond (aside from the codified methods intended for scholastic purposes) did not follow lines of development that can readily be assimilated to those described in the first part of this paper. Indeed, Marielle Abrioux's fine synthetic overview of international research in the field, published in 1995, makes no reference to the new developments, lest it be in the concluding remark where she draws attention to

the unjustly neglected question, to date, $[\ldots]$ of the difference between written narrative and oral narrative which, obviously, is to be confused neither with the distinction literary/non-literary nor with the distinction fictional/non-fictional. (Abrioux 1995: 200)

On the other hand, it is also notable that Abrioux's article appeared only one year after the German translation of Genette's Discours du récit: essai de méthode (1972) — fourteen years after the English translation... So what is true of "Anglo-American and French structuralist approaches to narrative," namely that they "underwent a kind of staggered development following parallel evolutionary trajectories at nonsynchronous rates of change" (Herman 2005a: 26), seems to hold for the development of narratology on a much wider scale, both classical and postclassical, and indeed for the multiple though occasionally intersecting paths followed by narrative theory since the end of the nineteenth century.

The year 1983 is also significant in that it saw the first tome of Paul Ricœur's three-volume Time and Narrative (1983-85). Through the perspective of phenomenological hermeneutics, Ricœur's work reintroduced into

6 Berthelot (2005a, 2010) demonstrates the pertinence of these two narratologies in his study of "transfictions"; examining a broad corpus of novels, he breaks transfictions down into narratives that transgress the order of the world and those that transgress the laws of narrative. For a presentation of the subject in English, see Berthelot (2005b). Cf. also Ilias Yocaris' seminar "Les récits transfictionnels" (University of Nice, 2011 and 2012). 
narrative theory an array of questions that narratologists, either by choice or as a result of methodology, had not addressed or had considered only marginally up to that time. Among the many issues debated in this major work, mention should be made in the present context of the three forms of mimesis that structure Ricœur's overall argument. ${ }^{7}$

Mimesis I corresponds to a "pre-comprehension of the world of action" in which any narrative plot is necessarily embedded. It is characterized not only by symbolic and temporal dimensions but also by a "conceptual network," making it possible to distinguish between action (consisting of goals, motivations, and agents) and physical movement. Within this conceptual network, a relation of presupposition and transformation is set up between "practical understanding" and "narrative understanding": as Ricœur points out, this has the consequence that the structural analysis of narrative ${ }^{8}$ implicitly or explicitly includes a phenomenology of "doing" (faire). Such a phenomenology prefigures and shares some traits with "storyworlds" as mental constructs in cognitive narratology. Mimesis II is the locus of semiotic mediation from which a science of the text can be derived. It is here that the operation of "configuration" takes place through "emplotment" (mise en intrigue), a notion derived from Aristotle's muthos and peripateia and from Augustine's philosophy of time. Not only does Ricœur discuss plot with reference to narratological models - a principle absent from classical narratology (cf. Pier 2008: 118-19)—but it is also at this level that the opposition fictional narrative/historical narrative appears, a distinction not drawn by classical narratologists. Finally, Mimesis III marks the intersection between the text world and the world of the addressee. This means, among other things, that the act of reading operates as a vector of the plot's ability to model experience and also that communication in narrative contexts raises a host of referential issues that were the bête noire of classical narratology and of structuralism in general. ${ }^{9}$

By situating narrative within these three forms of mimesis, Ricœur opened up enquiries which, at the time, lay upstream or downstream of the narratological models that had been developed under the aegis of structuralism. One of the key notions to emerge from this contribution, with many ramifications, is that of "narrative intelligence." It is distinct from the semiotic rationality that guides narratological theories which

7 The following summary is based on Ricœur (1984 [1983]: chap. 3).

8 By structural analysis of narrative, the work of Propp or Greimas is meant, although Bremond and other researchers working on the formal structure of narrative content could also be mentioned in this context.

9 Regarding the widely employed notion of "referential illusion," cf. Pavel (1986: 6). From the perspective of analytic philosophy and a possible worlds approach to literature, he denounces structuralism's "moratorium on representational topics." For a general critique of the use of linguistics by French structuralists, see Pavel (1989 [1988]). 
"dechronologize" narrative through attempts to model a narrative "logic." Such theories fail to account for time as a "temporality" which is experienced phenomenologically, a temporality whose vehicle in narrative, both fictional and factual, is emplotment.

The shift of parameters in the investigation of theoretical issues brought about by Ricœur's hermeneutic study of narrative is in fact part of a more general trend in French scholarship toward the development of non-narratological approaches as well as a reflection on narrative outside the literary disciplines. These developments cannot be meaningfully taken up here. Yet mention can be made, on an indicative basis, of a few contributions in the fields of philosophy, historiography, and anthropology.

Among philosophers, Time and Narrative has given rise to debates over such matters as the status of the theory of action in relation to plot, the problem of the narrative identity of the subject, the "intertwining" (entrecroisement) of fictional and historiographic writing through temporality, and the problematic articulation of narrative intelligence with hermeneutics, ethics, and poetics (cf. Bouchindhomme/Rochlitz 1990). In the theory of fiction, Jean-Marie Schaeffer (1999) has insisted on maintaining a distinction between fiction and narrative, terms that are far too often employed synonymously by literary critics. Fiction, he argues, is a universal ontogenetic competence essential for cognitive and affective development (children learn by adopting imaginary roles, etc.), while from a phylogenetic perspective it is a social activity which becomes a cultural institution once it takes the form of artistic representation. Schaeffer's theory of fiction integrates Plato's notion of mimesis as an "illusion" or an "as if" and mimesis in Aristotle which is understood as a cognitive modeling of actions according to necessity, verisimilitude or possibility. ${ }^{10}$ Being a form of mimetic modeling implemented by various means, its effects are reactivated through fictional immersion, a pre-attentional simulation triggered by mimetic "baits" through which the addressee enters a mentally projected world. ${ }^{11}$

In contrast to Schaeffer's pragmatic approach is the semanticallyoriented possible worlds literary theory. Due to the previous lack of translations of the major contributions into French, this area of research is hardly known in France. This situation has been remedied by the recent publication of a collection of articles by some of the leading possible worlds literary theorists. ${ }^{12}$

10 See also Schaeffer (2009: 103-4).

11 Schaeffer's book has stimulated further research and debate; see in particular Flahault/Heinich (2005). On fictional immersion, see Schaeffer/Vultur (2005).

12 This publication followed out of a seminar directed by Françoise Lavocat at the University of Paris 7 - Denis Diderot in 2005-06 (cf. Lavocat 2010). 
As for historiography, reference can be made to the writings of Hayden White, inspired in part by Ricœur, which focus on the literary form and narrative strategies adopted in the writing of history. Regarding the epistemology of historiography in the more specifically French context, Paul Veyne (1984 [1971]) critiqued both structuralist and Marxist theories as well as history as scientific explanation, and in doing so he defended the role of plot in the writing of history. The notion of "truth programs" is also put forth by Veyne (1988 [1983]). These are systems of belief that allowed the Greeks to accept myths as historically truthful, for instance, or other societies to treat stories of the sacred and of the profane according to differing standards of historical truth. In a historical case study, Louis Marin $(1978,1981)$ examined narrative as a form of political rhetoric or argumentation in the specific historical context of seventeenth-century France. The perspective is not one of the theoretical status of narrative or its constitutive features: rather, the writing of history, but also of fables, memoirs, travel narratives, etc., and the image of the monarch are seen as interdependent, forming a "trap" born out of a mutual exchange between the narrative of power and the power of narrative.

In the field of social anthropology, Marc Augé (1997) has studied "ethno-fictions," the circulation of fictions in society and their appearance at particular historical moments. Taking as a base situation the roles of narrator-agents and witness-narratees and the status of events in narratives of dreams as opposed to narratives of possession by shaman-like forces in African and Amerindian societies, Augé demonstrated, inter alia, that the narrator of dreams experiences the enigma of presence of a second self marked by alterity; by contrast, in narratives of possession by outside forces, the narrator is faced with the enigma of absence, a second self characterized by identity. In modern societies, faced with the confusion of reality and models (Baudrillard, Virilio) and with the end of the grands récits (Lyotard), these discursive positions have reappeared; however, they have merged with fictions in such a way as to combine the imaginary and memory in a wide gamut of collective and individual forms.

Studying ancient Greek texts, Claude Calame (2005, 2009 [2006]) has combined cultural and social (rather than structural) anthropology with a discourse analysis that places particular emphasis on the pragmatics of enunciation. Taking exception to Ricœur's Heideggerian conception of temporality, which seeks to resolve the aporias of the phenomenology of vulgar or objective time into "lived time," Calame proposes to restore non-phenomenological calendar time to the organization of social space. He recenters Ricœur's triple mimesis so as to complement emplotment with "putting into discourse" (mise en discours) at the level of configuration (Mimesis II), thus introducing a "linguistic time" distinct from calendar 
time, yet entertaining with it a complex set of relations. This textual system, together with an anthropological perspective, is applied to a corpus remote from modern literatures, and the implications of Calame's close analyses for a number of recent and current critical paradigms (structuralism, gender studies, philosophical idealism, neo-mysticism) are discussed. ${ }^{13}$ Focusing on a novel present-day phenomenon, Christian Salmon (2007) has investigated the social uses of narrative that have emerged with the spectacular growth of "storytelling" in the field of marketing. Beginning in the 1980s, the use of storytelling then passed on, thanks in part to the new technologies, to management techniques in the form of standardized human resources scenarios, multi-media simulations produced by Hollywood for the "virtual" training of combat soldiers, the "spin doctors" enlisted for electoral campaigns, and the engineering of political information. This form of "applied narratology," so to speak, comes on the heels of the "narrative turn."

In a way, Ricœur's Time and Narrative and the other narrative research programs summarized above can be seen as a variety of responses to structuralist narratology's failure to achieve its original aim, namely to develop a science of literature inspired by Saussure's similar ambition for semiology as a future science of signs. It is well known that shortly after his 1966 "Introduction," Barthes began to distance himself from this kind of project, precisely on the grounds of its "scientism." A number of his writings during this period bear witness to this change of heart ("L'effet de réel" [1968], "La mort de l'auteur" [1968], S/Z [1970], "De l'œuvre au texte" [1972], etc.). This new orientation is summed up in his programmatic "Texte (théorie du)" (1973) which outlines a negative hermeneutics drawing on certain positions adopted by Derrida, Kristeva, and the Tel Quel group. With the formulation of a certain number of postulates, Barthes outlines an approach whose effect is to undermine the very premises on which structural narrative analysis is based: the "crisis" of the sign resulting in the subversion of signification; the idea that every "metalanguage" is a language and that text "deconstructs" the language of communication; the principle that the act of enunciation (and thus of narration) produces not a meaning but a "significance" which cannot be studied in terms of the categories of communication, representation or expression or in those of linguistics and rhetoric. Moreover, Barthes turns his attention to the process of structuring (structuration) rather than structure, and he conceives of text as an intertextual tissue of past quotations rather than an empirical entity; referring to Kristeva, he opposes "phenotext" as the object of semiological or structural analysis to "geno-text," a

13 Regarding this critique, see esp. Calame (2009 [2006]). 
set of operations occurring in the subconscious which is formative of the human subject; a new form of analysis is proposed called "semanalysis" which conducts its investigations on the interface between linguistics and psychoanalysis; finally, the notion of écriture is presented as a textual strategy aimed at redefining the relation between sender and receiver, liberated from the formal constraints of genres and the language sciences.

A text theory reflecting these principles is illustrated in a well-known micro-analysis of Balzac's story, "Sarrasine." Here, Barthes, working the signifier from within so as to trace its "productivity" through the plurality of its five codes, points out that "for the plural text, there cannot be a narrative structure, a narrative grammar or a narrative logic" (Barthes 1970: 12). It is no less striking than significant that Francophone research, contrary to English-language scholarship, has devoted no effort to reformulating these notions into theories claiming the status of narratology, either poststructuralist (e.g., Gibson 1996) or postmodern (e.g., CornisPope 1990).

For all of Barthes's attempts to radically demarcate textual theory from his earlier theory of narrative, it is noteworthy that he continued to restrict linguistic analysis to the sentence, asserting that proposals to create a "linguistics of discourse" rely either on a rhetoric that is "outmoded," a stylistics that is "very limited" or a metalanguage that examines the utterance (énoncé) from the outside rather than enter into the textual space of enunciation (Barthes 1973: 1016). In fact, Barthes chose not to follow up on developments in transformational grammar, text linguistics, discourse analysis, conversation analysis, pragmatics, and the philosophy of language that had already begun to supersede structural linguistics. Rather, he took a new angle on structuralist principles which stemmed from Derrida's deconstructionism and which has been described by François Dosse as "ultra-structuralism": it consists of dismantling logocentrism through the radicalization of structural logic, a decentering that results in an infinite play of differences and deferral (cf. Dosse 1992: 30-47). For Francophone structuralism, and in particular for the narrative theories that followed out of it, the result was to orient narrative research in directions different from those which these theories might otherwise have taken. Nonetheless, as it has since become more evident, the legacy of the early narratology is to have "reconfigure[d] the relationship between critico-theoretical and linguistic analysis" (Herman 2001: \6).

From this perspective, classical narratology can be seen as laying the groundwork for a narrative theory rooted in a "textual science" or "sciences of the text." Such a textual science is not a sub-discipline of the natural sciences-the "scientism" shied away from by Barthes and his followers-but is closer to the German idea of a Textwissenschaft, that is, an 
organized body of concepts and of analytical and evaluative procedures brought to bear on discourse in its manifold forms, of which narrative is one variety. ${ }^{14}$ However much Saussurean-inspired linguistic models can be credited with contributing to the growth of methodologically sophisticated theories of narrative, it remains ill-suited to discourse-analytical paradigms extending beyond the sentence. ${ }^{15}$ In sum, classical narratology did not have at its disposal a sufficiently elaborated conceptual and methodological apparatus to carry through on the insights gained from the initial program.

\section{A French Postclassical Narratology? French Discourse Analysis}

With this brief overview of the principal lines along which postclassical narratology has developed and a few suggestions as to why Francophone narrative theory did not actively or directly participate in the "renaissance" of narratology, it is now possible to address the question of a properly French postclassical narratology. To the extent that French-speaking narratologists have not pursued the various "narratologies" cultivated in other countries, the answer to the question as to whether there exists a French postclassical narratology is "no." To date, the thematic and interpretive narratologies identified by Nünning have not taken root on French soil; where "applications" of narratological principles do exist (e.g., in explication de texte), they are often carried out in a piecemeal fashion and tend to be restricted to descriptive purposes serving ends that lose sight of the concepts, methods, and aims of narratological research.

However, viewed in the singular, rather than the plural, there is a body of research within the Francophone sphere that can be qualified as postclassical narratology. Broadly speaking, this research is carried on by theoreticians who have taken a critical stance with regard to the various concepts and analytical procedures focused on by classical narratology, although not with the aim of contesting or undermining the principled study of narrative in its numerous dimensions. Rather, in the spirit of the opening page of Barthes's 1966 essay, the project consists of thinking these concepts and analytical procedures through on the basis of paradigms that to various degrees have succeeded those of structuralism. The

14 Such a program has been outlined by Rastier (2001) who calls for a re-articulation of linguistics, semiotics, computer philology, "material" hermeneutics, rhetoric, stylistics, thematics, and general poetics within the framework of a semiotics of cultures.

15 The ambiguous "homological relation" between sentence and discourse postulated by Barthes (1977 [1966]: 83) was looked at in a different light by van Dijk (1972), for example, who spoke of textual microstructures and macrostructures. 
result, while not a "unified" narrative theory, can be described as coming within the scope of a textual science forming a branch of analyse du discours. This analyse du discours, or "discourse analysis," has developed along lines that are not wholly assimilable to the discourse analysis practiced in English-language scholarship, even though both are born out of the recognition of the need to study language beyond the limit of the sentence and to take account of the contextual and pragmatic features of discourse. ${ }^{16} \mathrm{It}$ reflects a fundamental and multifaceted mutation that took place starting in the late sixties with the eclipsing of structural linguistics and the rise of the autonomy of the text with its "codes" by factoring in the contextuality of meaning and of advances in text linguistics, sociolinguistics, psycholinguistics, the theory of argumentation, conversation analysis, stylistics, etc. As regards French discourse analysis employed in the theory of narrative, divergences of approach and emphasis do of course exist, but they cannot be said to have ramified into an array of narratologies tailored to the needs of specific themes, interpretive schools, disciplines, or objects of analysis.

For the sake of economy, my comments on French discourse analysis and its relevance to narrative theory will draw mainly on a number of publications by Jean-Michel Adam which situate narrative within a general theory of discourse that neither restricts narrative to text or to structure (structuralism), dissolves it into textualism (poststructuralism), nor assimilates all forms of discourse into narrative paradigms (the question of "narrative ubiquity"). ${ }^{17}$ Developing in a consistent manner from the mid-

16 "The term 'discourse analysis' has come to be used with a wide range of meanings [...] to describe activities at the intersection of disciplines as diverse as sociolinguistics, psycholinguistics, philosophical linguistics and computational linguistics" (Brown/Yule 1983: viii). For these authors, discourse analysis includes "transactional language" ("factual or propositional information") and "interactional language" ("use of language to establish and maintain social relationships”) (Brown/Yule 1983: 1-3). Van Dijk (1985) traces the emergence of discourse analysis (which he likens to Textwissenschaft) during the early 1970s to the refutation of formal, context-free transformational grammar as well as to speech act theory, text grammar, the link between research on artificial intelligence and the psychology of memory, conversation analysis, and the ethnography of communication. De Beaugrande (1985) points out that text linguistics and discourse analysis have developed in "a diverse and occasionally contrapuntal pattern" and calls for a research plan that will cover both text and discourse (1985: 41). More recently, in the "General Introduction" to a fourvolume anthology, Critical Discourse Analysis, Toolan states: "Because CDA always sees language as discourse, as construing and construed by social interests ('thought' or ideology, control, gender, class, race, politics), one of the first things to be noted is that it subscribes to a non-autonomous theory of language: languages are not studied as autonomous, homogeneous, structured objects, standing apart from the users and societies which sponsor and renew them" (Toolan 2002: xxiii).

17 On the ubiquity of narrative, see The Travelling Concept of Narrative (Hyvärinen/Korhonen/ Mykkänen 2006). This interesting sequel to Nünning (2003) contains several contributions devoted to an examination of the "narrative turn": e.g., Rimmon-Kenan (2006) points out that from the beginning, the concept narratology has borne the potential for broad expan- 
1970s to the present, Adam's research has integrated a wide variety of sources in the language sciences and literary theory. Like the work carried on by other specialists in the field, Adam's project suggests that discourse analysis, in a radical departure from structural linguistics as the "pilotscience" invoked by classical narratology, lies at the crossroads of the human sciences, notably linguistics, sociology, and psychology.

\section{Text and Discourse}

One basic conceptual factor to be taken into account is that where most narratological systems explicitly or implicitly adopt one version or another of the story/discourse pair, ${ }^{18}$ discourse analysis approaches its object of study from the broader perspective of text and discourse. ${ }^{19}$ Text can be viewed in two ways: 1) as the abstract object of text linguistics governed by texture, or cohesion (grammatical and stylistic dependencies at the microlinguistic level), and structure (a hierarchical relational network with a relatively autonomous internal organization at the macrolinguistic level) or; 2) as an utterance (énoncê), i.e., the singular empirical object resulting from an act of enunciation (énonciation) which forms the object of analysis of individual texts and takes into account the context of verbal interaction as well as intentionality (producer's attitude) and acceptability (receiver's attitude) (cf. Adam 2001 [1992]: 15; 1999: 40; 2005: 28-29; Charaudeau/Maingueneau 2002: 570-72; de Beaugrande/Dressler 1981). It will be noted that the emphasis here is on text and texts in general, and not any specific type of text, as terminologically presupposed by the story/discourse pair.

As for discourse, the term can refer to units of language beyond the sentence and thus to text (as in English usage). However, discourse also has other meanings, one of them included in Émile Benveniste's modes of utterance histoire/discours (cf. 1990 [1966]: 225-57)—an important source of the mainstream narratological distinction. ${ }^{20}$ From a different perspec-

sion into areas that have little to do with narrative, and she thus argues in favor of a reflection on the differentia specifica of narrative. Hyvärinen (2006) sees a divergence between narratological theories, which tend to debate the criteria of narrative, and narrative-turn theories that have radically expanded the range of narratives into the social sciences. Phelan (2005) has cautioned against the perils of "narrative imperialism."

18 I will not dwell on these polysemic and variously interpreted terms, but only refer the reader to the definitions of story and discourse in Prince (2003a [1987]: 21, 93). For a commentary, see Pier (2003: 78-83).

19 Note that Prince (2003a [1987]) includes no entry for "Text."

20 Briefly stated, histoire consists in third-person utterances that exclude "autobiographical" forms while discours, in the first and third persons, includes "all enunciations which assume 
tive, however, discourse in French linguistics is viewed as language put into context in the course of interpersonal or intersubjective transaction, and it is thus socio-historically situated. Moreover, discourse results from various restrictions imposed on language as a system (langue): a set of utterances within a given "discursive formation" (Foucault); type (e.g., political discourse), consisting of an open-ended variety of genres (televised debate, tract, etc.); the status of interlocutors (employer, employee, etc.); function (polemical, pedagogical, etc.) (cf. Charaudeau/Maingueneau 2002: 186, 592; Marnette 2005: 7).

A particular aspect of French discourse analysis, and one with farreaching consequences, is that it adopts a dual perspective on linguistic units beyond the sentence. As a verbal sequence with boundaries marked by a change of speakers, the linguistic unit is, on the one hand, an utterance (and not the sentence, i.e., a grammatical unit); as the trace of a socio-historically (and cognitively) determined act of communication, it is, on the other hand, discourse. A similar relation holds between a text understood as a linguistic unit produced by an act of enunciation and discourse. In this case, the same text is analyzed as a socio-discursive interaction: it takes the form of an oriented action between interlocutors subject to certain norms such as the grammatical rules of a given language and speech genres; ${ }^{21}$ furthermore, this oriented action occurs within a universe of other discourses. ${ }^{22}$ More specifically, text, according to Adam (cf. 1990: 23; 1999: 36-41; 2005: 19-20, 24, 31), is included within discourse, rather than the other way around. This marks a clear turn away from the structuralist notion of textual immanence and, a fortiori, from story and discourse in the standard narratological models. It reflects a more pragmatic conception of discursive practices and strategies of communication in that it highlights the context of conditions of textual production, reception, and interpretation. As a result, the analysis of individual discourses, which incorporates text linguistics as a sub-field, devotes particular attention to the complex interplay between textual determinations, which operate in a

a speaker and a hearer, the first intending to influence the other in some way" (Benveniste 1990 [1966]: 242); my emphasis.

21 The Baxtinian notion of speech genres will be taken up below.

22 Adam (1999: 85) likens interdiscursivity to Genette's (1997 [1982]: 1) "transtextuality": “all that sets a text in a relationship, whether obvious or concealed, with other texts." For the pre-eminence of interdiscourse over discourse, see Maingueneau (1987: 81-93) and Charaudeau/Maingueneau (2002: 324-26). Since the 1980s, Foucault's "discursive formations" have been largely relativized by interdiscourse, considered more neutral with regard to corpuses of a non-doctrinal nature and better adapted for analysis of the semiotic functioning of discourse (cf. Charaudeau/Maingueneau 2002: 269-72). For a critique of early French discourse analysis and its links with Althusserian dialectical materialism, see Rastier (2001: 243-46). On the relations between textuality and intertextuality, see Heidmann/Adam (2010). 
"bottom-up" fashion, and discursive determinations, the "top-down" regulation of utterances through social interaction and speech genres. ${ }^{23}$

\section{Discourse between Compositional Structure and Speech Genres}

Analysis of a discourse is predicated on the premise that textual units are subject to two types of textualization. The first, focused on by text linguistics, is revealed by the discontinuous segmentation of a text into texture (sentence grammar and relations beyond the sentence), compositional structure, semantics, enunciation (situational anchoring), and illocutionary orientation. The second, which is discourse-analytical, involves a process of "linkage" (liage) of units. Here, the basic unit is not the sentence (nor, for the narrative text, the function, motif, or move), but the "propositionutterance" (proposition-énoncé). This integrated discourse-oriented category consists of a syntactic micro-unit and a micro-unit of sense produced by an act of enunciation, and it includes a referential or propositional content and an argumentative orientation with an illocutionary force. Propositionutterances occur within both a linear succession (connectivity) and a hierarchical structure (sequentiality). They are bound together, first, by such devices as co-reference, anaphor, isotopy, and connectors and, second, are joined into rhythmic and lexico-morphological periods and macrosemantic sequences; these periods and sequences, in turn, are integrated into compositional and configurational units (cf. Adam 2001 [1992]: 4043; 1999: 43-80; 2005: 65-192).

As already noted, a key feature of Adam's formulation of discourse analysis is that it situates narrative within a broader theory of discourse. One important consequence of this critical decision is that the analysis of texts neither yields a typology of texts nor is predicated on the existence of such a typology. In fact, Adam specifically rejects such a typology, and in referring to work on this subject by (among others) Gülich, Werlich, Isenberg, and Longacre, he questions the notion of text types itself. Maintaining that texts are too complex and heterogeneous to be satisfactorily pigeonholed into typologies, he proposes as an alternative an open-ended

23 Cf. Charaudeau/Maingueneau (2002: 185-90, 221-23) and Marnette (2005: 8). In an analogous development but with emphasis on the pragmatics of enunciation, Calame (e.g., 2000 [1986], 2005) distinguishes between "intra-"/"extra-textual" and "intra-"/"extradiscursive," concepts derived from Benveniste, Jakobson, Bühler, and Greimas. Intradiscursive operations include assertion (marked by third-person "enuncive" shifters) and the assuming of these assertions by an instance of enunciation (marked by first- and second-person "enunciative" shifters). The point of origin of an enunciation results from a spatially and temporally situated "uttered enunciation" located between the utterances themselves and extra-discursive reality. 
system that conjoins the compositional structuring of sequence types with a theory of speech genres which serves to link the singular text to a Wittgensteinian "family of texts."

Compositional structure breaks down in Adam's model into five types of sequence: narrative; descriptive; argumentative; explanatory; dialogical. These sequences correspond not to text types but rather to prototypes, a notion which can be informally defined as cognitively based patterns of categorization that operate in a "more-or-less" fashion instead of in the categorial "either-or" manner. On this basis, a robin is perceived as more prototypically a "bird" than is an emus (centrality gradience) while the characterization of a man as "tall" shades off into neighboring categories of height (membership gradience). Applying this principle to discourse, it is clear that the singular text rarely if ever incarnates a single prototypeAdam insists on the compositional heterogeneity of texts-but instead implements combinations and dosages of the various prototypes either into heterogeneous sequential structures or into hybrid forms displaying a narrative dominant, a descriptive dominant, etc., according to the configuration peculiar to that text. Seen in this light, narrative is liberated from the monological unity ascribed to it by classical narratology. No longer is it the task of narratology (as in some of its earlier formulations) to formalize the "deep structure" of narrative out of which individual narratives are generated or, in abstracting from the sjuzhet, to determine the fabula that underlies or structures the singular text. Adam's discourse-based prototypical approach to text theory and analysis allows for a more plural conception of narrative.

Prototypically, narrative is modeled after the narrative sequence (cf. Adam 1999: esp. chap. 2). The coherence-building criteria of the sequence, drawn mainly from Bremond (1966), include: 1) succession of events; 2) thematic unity; 3) transformation of predicates; 4) integration of units into a same action; and 5) causality. The sequence itself is built up out of proposition-utterances grouped into five macro-propositions (initial situation, complication, actions, resolution, final situation), and it is given an overall configurational sense thanks to an evaluative macro-proposition which is either implicit or explicit (a "moral"). What sets the prototypical model of the narrative sequence off from its structuralist predecessor stems in large part from the evaluative macro-proposition, a feature taken by Adam from Labov and Waletzky's pathbreaking contribution to the analysis of conversational storytelling, and in particular from Labov's notion of "point," also referred to by narratologists as "tellability." 24 The importance of this aspect of Adam's theory is borne out, first of all, by the

24 For a recent overview of tellability, see Baroni (2009). 
configurational influence that strategies of evaluation exert on narrative discourse, sequence thus being integrated into Ricœur's Mimesis II, the locus of configuration and emplotment (see above); and secondly, it both underlies and underscores a textual pragmatics, initiated notably by Eco, ${ }^{25}$ but also with roots in Baxtin's sociolinguistics, that remained only latent in the classical models due to an overriding interest in identifying the constants of narrative structure and neglect of non-literary oral narration. ${ }^{26}$

In the analysis of discourses, the compositional structure of sequences is described essentially in terms of text linguistics. The pragmatic dimension, however, while textually discernible, also extends beyond strictly linguistic matters, coming within the broader scope of social interaction and socio-discursive context and thus opening a gap between linguistically describable features and these broader social and contextual considerations. As an interface between these two dimensions, Adam introduces Baxtin's notion of speech genres (Baxtin 1986 [1952-53]). ${ }^{27}$ According to Baxtin, the units of langue (language as an abstract system) do not combine directly or freely into units of parole (the individual act of enunciation). Between them lies a vast and varied assembly of "relatively stable forms," or speech genres, conditioned according to various social spheres (e.g., within the religious sphere, speech genres include the prayer, the sermon, etc.). Both prescriptive and normative, speech genres serve as a type of social codification without which communication would be impossible. They exist in primary (simple) forms (e.g., the unmediated verbal exchanges of everyday speech) and in secondary (complex) forms (literary texts, scientific reports, etc.) into which primary forms, which operate prototypically, are assimilated. A second feature of speech genres is that the "complete utterance" taken as a whole, marked by the change of speakers rather than by the grammatical sentence, consists not merely of a proposition but is inseparable from what one hopes to achieve in choosing one utterance or another. Adam's proposition-utterance (see above) together with the compositional structure of texts represents a translation of this principle into a discourse-analytical concept. Finally, faced with the heterogeneity of texts, Adam, skeptical of typologies of texts and opting instead for the prototypical typology of sequences discussed above, sees linguistic competence as governed by: 1) discursive constraints, i.e., histor-

25 See Eco (1979) in particular.

26 By adopting prototypes in place of text types, it may be the case that Adam has not so much rejected text types as provided them with a basis, in cognitive and sociolinguistic terms, for their reformulation. In this sense, Herman's (2009: esp. chap. 4) discussion of text types in a cognitive context represents an interesting sequel to Adam's prototypical narrative sequence. More generally, Adam's discourse analysis shares a number of common though heretofore little discussed concerns with Herman's cognitive narratology.

27 Cf. Adam (1999: 11-16; 2001 [1992]: 16-18, 60); Adam/Heidmann (2004). 
ical and social factors that influence the formation of speech genres (rather than text types); 2) textual constraints determining compositional structure; and 3) local constraints analyzed in accordance with the standard linguistic categories. "A [speech] genre," he states, "links what textual analysis describes linguistically to what the analysis of discursive practices seeks to apprehend socio-discursively" (Adam 1999: 83; emphasis in the original). What counts in the end, however, is not genre per se, which is a classificatory concept, but genericity:

Genericity is a socio-cognitive necessity that links all texts to the interdiscourse of a social formation. A text in itself does not belong to a genre. Rather, at the time of production and at that of reception-interpretation, it is put into relation with one or more genres. (Adam/Heidmann 2004: 62)

Or again: it is

less a matter of examining the generic membership of a text than of bringing to light the generic tensions that inform it. This displacement from genre to genericity suspends all typological concerns [and] makes it possible to bypass the pitfalls of essentialism. (Dion/Fortier/Hagueraert 2001: 17; quoted in Adam/Heidmann 2004: 63)

\section{Discourse: The Ongoing Issues}

The discourse analysis developed by Adam is not a specifically narrative theory but a theory that includes narrative as one of its objects. As is the case of discourse analysis generally speaking, it draws heavily on linguistics but at the same time seeks to bring within its scope a variety of discursive and socio-discursive phenomena that require either an expansion of linguistic paradigms or the adaptation of non-linguistic disciplines to the conditions and processes of discourse. At the risk of oversimplifying, it can be said that French narrative theory since the classical phase of narratology has generally followed two paths: either it has addressed questions raised by narratology but without necessarily claiming, or in some cases even refusing, the title of narratology, thus casting the new approach to narrative theory in a different light (the assimilation of narratological categories into a phenomenological hermeneutics by Ricœur in his Time and Narrative being the most consequential example); or it has evolved within the various frameworks offered by theories of discourse that got underway shortly after the birth of narratology and for which narratology was one source of momentum. Roughly speaking, theories of discourse as they have been developed in Francophone scholarship over the past few decades can be divided into three groups (cf. Petitjean 1989). 
Communicational theories, whose reference point is Jakobson's (1960) influential five-function model of verbal communication. Employed, often in revised form, in the analysis of numerous types of discourse, Jakobson's model has also played a role in the development of sender-receiver theories of narrative communication which include embedded levels beginning with the author-reader and extending through the implied author-implied reader, the narrator-narratee, and character-character exchanges. Among these theories is Genette's "modal" narratology with its concentration on analysis of the discourse level.

Enunciative theories, developing out of Benveniste's (1991 [1970]) definition of enunciation as the functioning of language implemented by the individual act of use. This orientation has resulted in enunciative linguistics, which has produced a large and diverse body of research in France, and it has also given rise to an enunciative narratology. 28 The basic postulate of such a narratology, according to René Rivara, is to consider

literary narration as a specific type of enunciation, making it possible to work out or elucidate properly narratological concepts (such as 'interior monologue') and to explain several fundamental properties of narrative. (Rivara 2000: 50)

Enunciatively inspired narrative theory, critical of Genette's position on focalization and speech representation, has re-examined these issues backed up with a more rigorous linguistic methodology. On this basis, Rivara $(2000,2004)$ has advocated a "narrator-centered" enunciative narratology which correlates viewpoints with first-person and third-person narration; in contrast, Alain Rabatel $(1998,2008,2010)$ has applied enunciative analysis to narrative phenomena (particularly viewpoints) by linking linguistic expression to perceptions, but without claiming for this analysis the status of a comprehensive theory of narrative. In her recent monograph on the narrator, Sylvie Patron (2009) has taken a critical stance with regard to the enunciativists' thesis of a "narrator-in-all-narratives" and, with reference to Hamburger, Kuroda, and Banfield, has called into question communication-based narrative theories.

Discourse analysis theories, classifying discourses according to situational or socio-historic criteria or, more recently, viewing discourse as the conjunction of "bottom-up" text linguistic determinations and "top-down" contextual and pragmatic factors. These theories, which bring narrative under a general theory of discourse, situate individual discourses in a universe of discourses (interdiscourse) and are thus characterized by a dialogical dimension. In reviewing Adam's work in this field, it has been shown how the compositional structure of narrative, for instance, when con-

28 For a more detailed account, see Sylvie Patron's contribution to this volume. The French version of this article is included as an appendix in Patron (2009). 
fronted with a prototypical model of the narrative sequence and speech genres, combines textual analysis with socio-discursive analysis.

These three orientations in theories of discourse are not exclusive of one another, but, in some respects, have resulted from overlapping concerns. ${ }^{29}$ Nor do these theories stake out the full range of present-day French narrative theory, Ricœur's influential work, for example, being a hermeneutic rather than a discourse-analytical approach. Even so, based on the premise that one essential common thread running through Francophone research in this area since the time of the initial narratological studies is that narrative is above all a form of discourse, I have attempted to show that narratology as currently practiced in French-speaking countries is postclassical to the extent that it builds critically on past work, but not in the sense that it can be declined into a plurality of narratologies. In this way, narratology conceived according to the postulates, goals, and methodologies of discourse analysis, even if the various approaches may diverge, is not one narratology among others; on the contrary, it provides a general conceptual framework for discourse within which the manifold aspects of narrative in all of its forms can be addressed. This being the case, the following points (at a minimum) can be made:

1) Narrative examined within a discourse-analytical paradigm such as the one proposed by Adam in which discourses are seen as the product of interaction between compositional structure, the configuration of prototypes, and speech genres pre-empts any over-expansion of categorizations derived from story/discourse theories: a theory that accommodates the heterogeneity of texts relativizes any assumption as to the primacy of narrative discourse or the idea, implicit or explicit, that discourse in general is structured according to the criteria of narrative. ${ }^{30}$

2) Because it includes corpuses from all speech genres, French discourse analysis does not need to export categories, paradigms, and methodologies - narrative or otherwise-when examining discourses that are not predominantly of one kind or another; by the same token, a narratology rooted in discourse analysis does not need to propose different narratologies in order to accommodate different corpuses or analyze various aspects of narrative, but only adapt its focus accordingly.

29 Thus enunciative narratology, for example, was formulated partly in response to categories first set out by Genette; moreover, Marnette (2005: 13 passim) has examined speech and thought presentation within the context of Adam's sequence types and speech genres. Rabatel's (2008) important two-volume study of dialogism and polyphony in narrative merits particular attention with regard to enunciative and interactional issues.

30 Cf. Herrnstein Smith (1981: 228): “Almost any verbal utterance will be laced with more or less minimal narratives, ranging from fragmentary reports and abortive anecdotes to those more distinctly framed and conventionally marked tellings that we are inclined to call 'tales' or 'stories." 
3) Contrary to story/discourse theories, a discourse-analytical approach to narrative results in the inclusion of text within discourse. The ensuing move away from text typologies toward prototypes (or toward a prototypical conception of texts) is consistent with the general trend in the field of literary theory and criticism toward the contextual structuring of discourse in the process of reception.

The last point in particular leads to the question of how and to what degree a discourse-analytical narratology might tally with Nünning's "context-oriented" narratologies. Without further theoretical work and the examination of appropriate corpuses, this question must of course remain open. Yet it does seem clear that, on the matter of the contextualization of narrative categories, Francophone discourse-analytical theories differ significantly from the current postclassical position. Thus the discourseanalytical approach does not rule out, for instance, the genderization of narrative: it sees nothing in compositional structure which is inherently gendered (pronouns, plot structure, etc.) but seeks, rather, to account for this feature in accordance with socio-discursive factors. Moreover, expansion of the corpus is viewed by this approach not so much as a response to the ubiquity of narrative but as a correlate of the heterogeneity of forms of discourse.

Among the broader implications of Francophone narratology as presented in this paper, two in particular appear to call for some comment. First, the pertinent locus of narrative structuring is to be found neither in text nor in context, but in the interface between the two. This can be attributed in large part to the prototypical dimension of discourse-analytical narrative theory, and in particular to the idea that narrative sequences are more or less pronounced according to the pragmatic and contextual criteria to which they are subject, as opposed to the "deep structure" of earlier theories out of which narratives are purportedly generated. Second, a narratology rooted in discourse analysis may well offer an alternative to the "centrifugal force" (Barry 1990) that has contributed to the proliferation of narratologies. This tendency stems from the need to overcome the constraints imposed by "text-centered" classical narratology through the introduction of a more open array of "context-oriented" postclassical narratologies. It is a consequence of the division of narrative into story and discourse, itself a lingering heritage of Saussurean langue and parole. By contrast, the inclusion of speech genres and genericity in Francophone discourse-analytical narratology, by focusing on the tensions that prevail in individual discourses, offers a possible solution to the alternative between textualism and contextualism that has marked so much of narratology throughout its development. 
Such then are some of the issues that place the discourse-analytical approach within the scope of postclassical narratology. By questioning and reordering the premises of narratology in relation to forms of discourse other than narrative, Francophone discourse-analytical narratology positions itself within the broader question of a semiotics of cultural representation rather than as one narratology among others. ${ }^{31}$

\section{References}

Abrioux 1995

Abrioux, Marielle: "Narratologie," in Nouveau dictionnaire des sciences du langage, edited by Oswald Ducrot and Jean-Marie Schaeffer, 191-201 (Paris: Seuil). Adam 1994 [1985] Adam 1990

Adam, Jean-Michel: Le texte narratif: précis d'analyse textuelle, (Paris: Nathan).

Adam, Jean-Michel: Éléments de linguistique textuelle (Brussels/Liège: Mardaga). Adam 2001 [1992] Adam 1999

Adam, Jean-Michel: Les textes: Types et prototypes, $4^{\text {th }}$ ed. (Paris: Nathan).

Adam, Jean-Michel: Linguistique textuelle: Des genres de discours aux textes (Paris: Nathan).

Adam 2005

Adam, Jean-Michel: La linguistique textuelle: Introduction à l'analyse textuelle des discours (Paris: A. Colin).

Adam/Heidmann 2004

Adam, Jean-Michel/Heidmann, Ute: "Des genres à la généricité: L'exemple Augé 1997

des contes (Perrault et les Grimm)," in Langages 153: 62-72.

Baroni 2009

Augé, Marc: La guerre des rêves: Exercices d'ethno-fiction (Paris: Seuil).

Baroni, Raphaël: "Tellability," in Handbook of Narratology, edited by Peter Hühn, John Pier, Wolf Schmid and Jörg Schönert, 447-54 (Berlin/New York: Barry 1990 de Gruyter).

Barry, Jackson G.: "Narratology's Centrifugal Force: A Literary Perspective on the Extensions of Narrative Theory," in Poetics Today 11.2: 727-53.

Barthes 1977 [1966]

Barthes, Roland: "Introduction to the Structural Analysis of Narratives," in Image, Music, Text, translated by Stephen Heath, 79-124 (New York: Hill and Wang).

Barthes 1970

Barthes, Roland: $S / Z$ (Paris: Seuil).

31 I wish to thank Philippe Roussin for his insightful reading of this article and valuable suggestions as well as Greta Olson and Birte Christ for their exceptional editorial feedback. 
Barthes 1973

Barthes, Roland: “Texte (théorie du)," in Encylopadia Universalis, vol. XV: 1013 17.

Baxtin (Bakhtin) 1986 [1952-53]

Baxtin, Mikhail: "The Problem of Speech Genres," in Speech Genres and Other Late Essays, edited by Caryl Emerson and Michael Holquist, translated by Vern W. McGee, 60-102 (Austin: University of Texas Press).

de Beaugrande 1985

de Beaugrande, Robert A.: Writing Step by Step: A Textbook for College Writers

(New York: Harcourt Brace Jovanovich).

de Beaugrande 2002

de Beaugrande, Robert A.: "Text Linguistics in Discourse Studies," in Critical Discourse Analysis: Critical Concepts in Linguistics, vol. 1, edited by Michael Toolan, 41-70 (London/New York: Routledge).

de Beaugrande/Dressler 1981

de Beaugrande, Robert A./Dressler, Wolfgang: Introduction to Text Linguistics (London/New York: Longman).

Benveniste 1990 [1966]

Benveniste, Émile: Problèmes de linguistique générale (Paris: Gallimard).

Benveniste 1991 [1970]

Benveniste, Émile: "L'appareil formel de l'énonciation," in Problèmes de linguistique générale, vol. 2, 79-88 (Paris: Gallimard).

Berthelot 2005a

Berthelot, Francis: Bibliothèque de l'Entre-Mondes: Guide de lecture, les transfictions (Paris: Gallimard).

Berthelot 2005b

Berthelot, Francis: "Transgressive Fictions," in Routledge Encyclopedia of Narrative Theory, edited by David Herman, Manfred Jahn and Marie-Laure Ryan, 613-15 (London/New York: Routledge).

Berthelot 2010

Berthelot, Francis: "Narratologie thématique et narratologie structurale: Le cas des transfictions," in Narratologies contemporaines: Paradigmes nouveaux pour la théorie et l'analyse du récit, edited by John Pier and Francis Berthelot, 76-91 (Paris: Éditions des Archives contemporaines).

Bouchindhomme/Rochlitz 1990

Bouchindhomme, Christian/Rochlitz, Rainer: "Temps et récit" de Paul Riccur en débat (Paris: Éditions du Cerf).

Bremond 1966

Bremond, Claude: "La logique des possibles narratifs," in Communications 8: 60-76.

Brown/Yule 1983

Brown, Gillian/Yule, George: Discourse Analysis (Cambridge: Cambridge University Press).

Calame 2000 [1986]

Calame, Claude: Le récit en Grèce ancienne: Enonciation et représentations de poètes, preface by Jean-Claude Coquet (Paris: Méridiens Klincksieck). 
Calame 2005

Calame, Claude: Masks of Authority: Fiction and Pragmatics in Ancient Greek Poetics. translated by Peter M. Burk (Ithaca, NY/London: Cornell University Press).

Calame 2009 [2006]

Calame, Claude: Poetic and Performative Memory in Ancient Greece: Heroic Reference and Ritual Gestures in Time and Space (Cambridge, MA/London: Harvard University Press).

Charaudeau/Maingueneau 2002

Charaudeau, Patrick/Maingueneau, Dominique (eds.): Dictionnnaire d'analyse $d u$ discours (Paris: Seuil).

Cornis-Pope 1990

Cornis-Pope, Marcel: "Poststructuralist Narratology and Critical Writing: A Figure in the Carpet Workshop," in Journal of Narrative Technique 20.2: 245-65.

van Dijk 1972

van Dijk, Teun A.: Some Aspects of Text Grammars: A Study in Theoretical Linguistics and Poetics (The Hague: Mouton).

van Dijk 1985

van Dijk, Teun A. (ed.): "Introduction: Discourse Analysis as a New CrossDiscipline," in Handbook of Discourse Analysis, vol. 1, 1-10 (London et al.: Academic Press).

Dion/Fortier/Hagueraert 2001

Dion, Robert/Fortier, Frances/Hagueraert, Elisabeth (eds.): Enjeux des genres dans les écritures contemporaines (Quebec: Éditions Nota bene).

Dosse 1992

Dosse, François: Histoire du structuralisme. II. Le chant du cygne, 1967 à nos jours (Paris: Éditions la Découverte).

Eco 1979

Eco, Umberto: The Role of the Reader: Explorations in the Semiotics of Text (Bloomington: Indiana University Press).

Flahault/Heinich 2005

Flahault, François/Heinich, Nathalie: "La fiction, dehors, dedans," in Vérités de la fiction. L'bomme. Revue française d'anthropologie 175-176.3/4: 7-18.

Fludernik 1996

Fludernik, Monika: Towards a 'Natural' Narratology (London/New York: Routledge).

Fludernik 2005

Fludernik, Monika: "Histories of Narrative Theory (II): From Structuralism to the Present," in A Companion to Narrative Theory, edited by James Phelan and Peter J. Rabinowitz, 36-59 (Malden, MA: Blackwell Publishing Ltd).

Genette 1980 [1972]

Genette, Gérard: Narrative Discourse: An Essay in Method, translated by Jane E. Lewin, foreword by Jonathan Culler (Ithaca, NY: Cornell University Press) Genette 1997 [1982]

Genette, Gérard: Palimpsests: Literature in the Second Degree, translated by Channa Newman and Claude Doubinsky, foreword by Gerald Prince (Lincoln/London: University of Nebraska Press). 
Genette 1988 [1983]

Genette, Gérard: Narrative Discourse Revisited, translated by Jane E. Lewin (Ithaca, NY: Cornell University Press).

Gibson 1996

Gibson, Andrew: Towards a Postmodern Theory of Narrative (Edinburgh: Edinburgh University Press).

Greimas 1983 [1966]

Greimas, A. J.: Structural Semantics: An Attempt at a Method, translated by Danielle McDowell, Ronald Schleifer and Alan Velie (Lincoln: University of $\mathrm{Ne}$ braska Press).

Heidmann/Adam 2010

Heidmann, Ute/Adam, Jean-Michel: Textualité et intertextualité des contes (Paris: Classiques Garnier).

Herman 1997

Herman, David: "Scripts, Sequences, and Stories: Elements of a Postclassical Narratology," in PMLA 112.5: 1046-59.

Herman 1999

Herman, David (ed.): “Introduction: Narratologies," in Narratologies: New Perspectives on Narrative Analysis, 1-30 (Columbus: Ohio State University Press).

Herman 2001

Herman, David: "Sciences of the Text," in Postmodern Culture 11.3. <http:// www.iath.virginia.edu/pmc/ text-only/issue.501/ 11.3 herman.txt $>$ (August 24, 2008).

Herman 2002

Herman, David: Story Logic: Problems and Possibilities of Narrative (Lincoln/London: University of Nebraska Press).

Herman 2005a

Herman, David: "Histories of Narrative Theory (I): A Genealogy of Early Developments," in A Companion to Narrative Theory, edited by James Phelan and Peter J. Rabinowitz, 19-35 (Malden, MA: Blackwell Publishing Ltd.).

Herman 2005b

Herman, David: "Structuralist Narratology," in Routledge Encyclopedia of Narrative Theory, edited by David Herman, Manfred Jahn and Marie-Laure Ryan, 571-76 (London/New York: Routledge).

Herman 2009

Herman, David: Basic Elements of Narrative (Maldon, MA: Wiley-Blackwell).

Herman/Jahn/Ryan 2005

Herman, David/Jahn, Manfred/Ryan, Marie-Laure (eds.): Routledge Encyclopedia of Narrative Theory (London/New York: Routledge).

Herrnstein Smith 1981

Herrnstein Smith, Barbara: "Narrative Versions, Narrative Theories," in On Narrative, edited by W. J. T. Mitchell, 209-32 (Chicago/London: University of Chicago Press).

Hyvärinen 2006

Hyvärinen, Matti: "Towards a Conceptual History of Narrative," in The Travelling Concept of Narrative. Collegium, vol. 1, edited by Matti Hyvärinen, Anu Korhonen and Juri Mykkänen. http://www. helsinki.fi/collegium/eseries/volumes/volume_1/index.htm (October 20, 2008). 
Hyvärinen/Korhonen/Mykkänen 2006

Hyvärinen, Matti/Korhonen, Anu/Mykkänen, Juri (eds.): The Travelling Concept of Narrative. Collegium, vol. 1. <http://www. helsinki.fi/collegium/eseries/volumes/volume_1/index.htm>.

Jakobson 1960

Jakobson, Roman: "Closing Statement: Linguistics and Poetics," in Style in

Language, edited by Thomas A. Sebeok, 350-77 (Cambridge, MA: M.I.T.

Press).

Kindt/Müller 2003

Kindt, Tom/Müller, Hans-Harald (eds.): "Narrative Theory and/or as Theory of Interpretation," in What is Narratology? Questions and Answers Regarding the Status of a Theory, 205-19 (Berlin/New York: de Gruyter).

Lavocat 2010

Lavocat, Françoise (ed.): La théorie littéraire des mondes possibles (Paris: CNRS Editions).

Lévi-Strauss 1967 [1955]

Lévi-Strauss, Claude: “The Structural Study of Myth," in Structural Anthropology, translated by C. Jacobson and B. G. Schoepf, 213-19, 229-30 (London: Allen Lane).

Maingueneau 1987

Maingueneau, Dominique: Nouvelles tendances dans l'analyse du discours (Paris: Hachette).

Maingueneau 1991

Maingueneau, Dominique: L'analyse du discours (Paris: Hachette).

Maingueneau 2000

Maingueneau, Dominique: "Les nouvelles relations entre études littéraires et sciences du langage," in Etudes romanesques 6: 7-21.

Marin 1978

Marin, Louis: Le récit est un piège (Paris: Seuil)

Marin 1981

Marin, Louis: Le portrait du roi (Paris: Minuit).

Marnette 2005

Marnette, Sophie: Speech and Thought Representation in French: Concepts and Strategies (Amsterdam/Philadelphia: John Benjamins).

Nünning 2003

Nünning, Ansgar: "Narratology or Narratologies? Taking Stock of Recent Developments, Critique and Modest Proposals for Future Uses of the Term," in What is Narratology? Questions and Answers Regarding the Status of a Theory, edited by Tom Kindt and Hans-Harald Müller, 239-75 (Berlin/New York: de Gruyter). (French: "Narratologie ou narratologies? Un état des lieux des développements récents: critique et propositions pour de futures usages du terme," in Narratologies contemporaines: paradigmes nouveaux pour la théorie et l'analyse du récit, edited by John Pier and Francis Berthelot, 15-45 (Paris: Éditions des Archives contemporaines [2010]).

Patron 2009

Patron, Sylvie: Le narrateur: introduction à la théorie narrative (Paris: A. Colin) 
Pavel 1986

Pavel, Thomas G.: Fictional Worlds (Cambridge, MA/London: Harvard University Press).

Pavel 1989 [1988]

Pavel, Thomas G.: The Feud of Language: A History of Structuralist Thought, transPetitjean 1989 lated by Linda Jordan and Thomas G. Pavel (Oxford: Basil Blackwell).

Phelan 2005

Petitjean, André: "Les typologies textuelles," in Pratiques 62: 86-125.

Phelan, James: "Who's Here? Thoughts on Narrative Identity and Narrative Imperialism," in Narrative 13.3: 205-10.

Pier 2003

Pier, John: "On the Semiotic Parameters of Narrative: A Critique of Story and Discourse," in What is Narratology? Questions and Answers Regarding the Status of a Theory, edited by Tom Kindt and Hans-Harald Müller, 73-97 (Berlin/New Pier 2008 York: de Gruyter).

Pier, John: "After this, therefore because of this," in Theorizing Narrativity, edited by John Pier and José Ángel García Landa, 109-40 (Berlin/New York: de Gruyter).

Pier/Berthelot 2010

Pier, John/Berthelot, Francis (eds.): Narratologies contemporaines: paradigmes nouveaux pour la théorie et l'analyse du récit (Paris: Éditions des Archives contemporaines).

Prince 1982

Prince, Gerald: Narratology: The Form and Functioning of Narrative (Berlin/New York/Amsterdam: Mouton Publishers).

Prince 1995

Prince, Gerald: "Narratology," in The Cambridge History of Literary Criticism. Vol. VIII: From Formalism to Poststructuralism, edited by Raman Selden, 110-30 (Cambridge: Cambridge University Press).

Prince 2003a [1987]

Prince, Gerald: Dictionary of Narratology (Lincoln/London: University of Nebraska Press).

Prince 2003b

Prince, Gerald: "Narratologie classique et narratologie post-classique," in Vox Poetica. Théorie et critique. <http://vox-poetica.org /t/prince06.html> (August 20, 2008).

Rabatel 1998

Rabatel, Alain: La construction textuelle du point de vue (Paris: Delachaux et Niestlé).

Rabatel 2008

Rabatel, Alain: Homo narrans. Pour une analyse énonciative et interactionnelle du récit, 2 vols. (Limoges: Lambert-Lucas).

Rabatel 2010

Rabatel, Alain: "Pour un narratologie énonciative ou une analyse enunciative des phénomènes narratifs?" in Narratologies contemporaines: paradigmes nouveaux 
pour la théorie et l'analyse du récit, edited by John Pier and Francis Berthelot, 110 39 (Paris: Éditions des Archives contemporaines).

Rastier 2001

Rastier, François: Arts et sciences du texte (Paris: Presses universitaires de France).

Ricœur 1984 [1983]

Ricour, Paul: Time and Narrative, translated by K. McLaughlin and D. Pellauer (Chicago: University of Chicago Press).

Rimmon-Kenan 2002 [1983]

Rimmon-Kenan, Shlomith: Narrative Fiction: Contemporary Poetics, $2^{\text {nd }}$ ed. (London/New York: Routledge).

Rimmon-Kenan 2006

Rimmon-Kenan, Shlomith: "Concepts of Narrative," in The Travelling Concept of Narrative. Collegium, vol. 1, edited by Matti Hyvärinen, Anu Korkonen and Juri Mykkänen Korkonen, Mykkänen. <http://www.helsinki.fi/collegium/eRivara 2000 series/volumes/ volume_1/index.htm> (October 20, 2008).

Rivara, René: La langue du récit: Introduction à la narratologie énonciative (Paris: L'Harmattan).

Rivara 2004

Rivara, René: "A Plea for a Narrator-Centered Narratology," in The Dynamics of Narrative Form: Studies in Anglo-American Narratology, edited by John Pier, 83Ryan 2005

113 (Berlin/New York: de Gruyter).

Ryan, Marie-Laure: "Narrative," in Routledge Encyclopedia of Narrative Theory, edited by David Herman, Manfred Jahn and Marie-Laure Ryan, 344-48 (London/New York: Routledge).

Salmon 2007

Salmon, Christian: Storytelling: la macbine à fabriquer des histoires et à formater les esprits (Paris: La Découverte).

Schaeffer 1999

Schaeffer, Jean-Marie: Pourquoi la fiction? (Paris: Seuil). Schaeffer 2009

Schaeffer, Jean-Marie: "Fictional vs. Factual Narration," in Handbook of Narratology, edited by Peter Hühn, John Pier, Wolf Schmid and Jörg Schönert, 98114 (Berlin/New York: de Gruyter).

Schaeffer/Vultur 2005

Schaeffer, Jean-Marie/Vultur, Ioana: "Immersion," in Routledge Encyclopedia of Narrative Theory, edited by David Herman, Manfred Jahn and Marie-Laure Ryan, 237-39 (London/New York: Routledge).

Todorov 1969

Todorov, Tzvetan: Grammaire du "Décaméron" (The Hague: Mouton). Toolan 2002

Toolan, Michael (ed.): "General Introduction," in Critical Discourse Analysis: Critical Concepts in Linguistics, 4 vols., xxi-xxvi (London/New York: Routledge). Veyne 1984 [1971]

Veyne, Paul: Writing History: Essay on Epistemology, translated by Mina MooreRinvolucri (Middlebury, CN: Wesleyan University Press). 
Veyne 1988 [1983]

Veyne, Paul: Did the Greeks Believe Their Myths? An Essay on the Constitutive Imagination, translated by Paula Wissing (Chicago, IL: Chicago University Press). 